\title{
PENGEMBANGAN PERANGKAT PEMBELAJARAN MODEL TPS DENGAN MEDIA LECTORA INSPIRE UNTUK MENINGKATKAN HASIL BELAJAR SISWA
}

\author{
Zulkifli Zakaria ${ }^{1)}$ \\ Wasis $^{2)}$ \\ Wahono Widodo ${ }^{3)}$ \\ ${ }^{1)}$ Mahasiswa Program Studi Pendidikan Sains, Program Pascasarjana Universitas Negeri Surabaya \\ ${ }^{2}$ Dosen Program Studi Pendidikan Sains, Program Pascasarjana Universitas Negeri Surabaya \\ ${ }^{3)}$ Dosen Program Studi Pendidikan Sains, Program Pascasarjana Universitas Negeri Surabaya \\ e-mail:zulkiflifis@yahoo.com
}

\begin{abstract}
Abstrak: Penelitian ini bertujuan untuk mengembangkan perangkat pembelajaran model TPS dengan media Lectora Inspire pada pokok bahasan hukum Newton untuk siswa SMA. Pengembangan perangkat pembelajaran menggunakan model 4-D. Ujicoba II dilakukan pada 90 siswa, dengan desain one group pretest-posttest dan dilakukan replikasi pada kelas X-1, X-2, dan X-3 SMA Negeri Mojoagung. Hasil penelitian menunjukkan: (1) Perangkat pembelajaran yang dikembangkan meliputi: RPP, buku siswa, LKS, media Lectora Inspire, dan tes hasil belajar berkategori layak dengan skor penilaian 3,9-4,0 dengan reliabilitas $81 \%-93 \%$. (2) Perangkat pembelajaran yang dikembangkan tergolong praktis, hal ini ditunjukkan oleh: (a) Keterlaksanaan RPP berkategori baik, dan terlaksana 100\% dengan reliabilitas 94\%, (b) Aktivitas siswa paling menonjol adalah mengajukan/menjawab pertanyaan yang ada dalam Lectora Inspire, (c) respon siswa terhadap pembelajaran dengan media Lectora Inspire adalah positif, dan (3) Hasil belajar siswa mengalami peningkatan, hal ini ditunjukkan oleh peningkatan skor rata-rata pretest 34,7-43,0 dan untuk skor rata-rata postest 79,8-85,5 dengan normalized-gain 0,68-0,74, (4) kendala yang dihadapi adalah siswa belum terbiasa dengan model pembelajaran TPS, siswa belum terbiasa untuk menghubungkan antara motivasi belajar berupa video dengan materi yang akan dipelajari. Berdasarkan hasil penelitian, maka dapat disimpulkan bahwa perangkat pembelajaran model TPS dengan media Lectora Inspire yang dikembangkan efektif untuk meningkatkan hasil belajar siswa pada materi Hukum Newton.
\end{abstract}

Kata-kata Kunci: media Lectora Inspire, pembelajaran think-pair-share (TPS), hasil belajar.

\begin{abstract}
This study aimed to develop learning material of TPS Model by using Lectora Inspire Media on the main subject of Newton's Law for Senior High School students. The Learning material development uses 4-D Model. Tryout II had been done to 90 students, by using one group pretest-posttest design and the replication to class $X-1, X-2$, and X-3 in SMA Negeri Mojoagung. The result of study shows: (1) The learning material that developed consists of: Lesson Plan, Students' Book, Students' Work Sheets, Lectora Inspire media, and the learning result assessment with worthy category are 3,9-4,0 and the reliability are 81\% -93\%. (2) The developed learning material is relatively practicable, it is showed by: (a) the Lesson plan implementation is well categorized, and $100 \%$ implemented with $94 \%$ reliability, (b) the most dominant of students' activity are asking and answering the questions in Lectora Inspire Media, (c) The students' response toward the lesson using Lectora Inspire Media is positive, and (3) The students' learning result is increase, it is shown by the increasing of pretest average score is 34,7-43,0 and the posttest average score is 79,8-85,5 with normalized-gain 0,68-0.74, (4) the constrains that faced are the students are not familiar with TPS model, the students are not familiar to connect between the video of motivation to learn with the material that will be learned. Based on the study, it can be concluded that Learning material of TPS Model with Lectora Inspire Media which developed is effective to increase the students learning result of Newton's Law material.
\end{abstract}

Keywords: lectora inspire media, think-pair-share (TPS) lesson, learning result.

\section{PENDAHULUAN}

Perkembangan teknologi dan informasi begitu pesat. Perkembangan tersebut membawa masyarakat memasuki era globalisasi. Teknologi merupakan suatu penemuan penting yang memiliki peranan penting bagi kehidupan. Teknologi dibuat atas dasar ilmu pengetahuan dengan tujuan untuk mempermudah pekerjaan manusia. Saat ini teknologi berkembang pesat di segala bidang, salah satunya di bidang pendidikan. Salah satu contoh perkembangan teknologi dalam dunia pendidikan adalah pembelajaran berbasis multimedia (Daryanto, 2010).

Tuntutan layanan profesional di berbagai sektor kehidupan dan kualitas sumber daya manusia yang memenuhi harapan masyarakat terus diperlukan. Tuntutan layanan profesionalisme ini juga muncul di dunia pendidikan. Pelayanan pendidikan yang efektif dan tepat sesuai dengan perkembangan teknologi dan informasi menjadi pilihan yang tidak bisa dihindari. Berdasarkan tuntutan layanan tersebut, maka guru dituntut untuk menguasai IT serta mempunyai kemampuan untuk memanfaatkannya dalam pembelajaran.

Berdasarkan data hasil belajar Fisika pada ulangan harian maupun ulangan tengah semester ganjil untuk materi Hukum Newton di SMAN Mojoagung tahun pelajaran 2012/2013, jumlah siswa yang tuntas $35 \%$, dan tidak tuntas $65 \%$. Hal ini mengindikasikan bahwa pemahaman siswa terhadap materi pelajaran belum optimal yang berakibat pada rendahnya jumlah siswa yang mencapai ketuntasan belajar. Berdasarkan hasil ulangan harian dan ulangan tengah semester ganjil tersebut, maka kurangnya pemahaman siswa terhadap materi pelajaran dapat disebabkan oleh berbagai faktor 
yang sangat kompleks. Salah satunya adalah lemahnya metode yang digunakan guru dalam menyampaikan materi Hukum Newton.

Peningkatkan mutu pendidikan juga perlu ditunjang adanya pembaharuan di bidang pendidikan itu sendiri. Salah satu caranya adalah melalui peningkatan kualitas pembelajaran yaitu dengan pembaharuan pendekatan atau peningkatan relevansi metode mengajar guru. Metode mengajar dikatakan relevan jika dalam prosesnya mampu mengantarkan siswa mencapai tujuan pendidikan melalui pembelajaran. Peningkatan kualitas pembelajaran tersebut dapat dibantu oleh penggunaan media pembelajaran yang relevan pula. Berdasarkan paradigma kontruktivisme penggunaan media menempati posisi yang cukup strategis dalam mewujudkan kegiatan pembelajaran yang optimal (Palupi, 2011). Tetapi peran media tidak bermaksud untuk menggantikan pengamatan secara langsung.

SMAN Mojoagung adalah SMA yang telah menerapkan pembelajaran dan administrasi berbasis IT. Sistem pembelajaran yang telah digunakan berbasis IT adalah: (1) Simajest (sistem penilaian berbasis web), (2) Sistem koreksi LJK, (3) Exsys (Examination System). Sistem administrasi berbasis IT yang telah digunakan berbasis IT adalah: (1) PAS (paket aplikasi sekolah - Nasional), (2) Sistem pendataan alumni, (3) PDSS (pusat data siswa dan sekolah - Nasional), (3) DAPODIKMEN (data pokok pendidikan menengah), (4) Padamu Negeri (data guru - Nasional). Berdasarkan hal tersebut, maka tepatlah kiranya pembelajaran di SMAN Mojoagung diterapkan dengan menggunakan media pembelajaran berbasis IT.

Upaya yang dapat dilakukan untuk mengatasi hal tersebut adalah dengan mengembangkan kualitas pembelajaran, peningkatan mutu tenaga pengajar, serta lingkungan belajar yang kondusif dan memadai. Salah satu cara untuk menyelesaikan permasalahan tersebut, khususnya yang berkaitan dengan lingkungan belajar yang kondusif dan menarik adalah penggunaan media Lectora Inspire. Sudjana dan Rivai (1997) mengidentifikasi, dengan memilih perpaduan media yang sesuai, hasil belajar seseorang dapat ditingkatkan. Dengan menggunakan media pembelajaran dalam proses belajar mengajar akan diperoleh banyak manfaat, diantaranya pengajaran akan lebih menarik perhatian siswa dan materi pengajaran akan lebih dipahami oleh para siswa.

Lectora Inspire dapat memudahkan gur im pembuatan media pembelajaran berbasis IT. Berdasarkan hasil angket yang diberikan kepada 20 guru di SMAN Mojoagung, 16 guru (80\%) menyatakan bahwa Lectora Inspire memiliki lebih banyak fitur khususnya terkait web, karena Lectora Inspire berbasis web bila dibandingkan dengan media powerpoint yang selama ini digunakan. Berdasarkan angket tersebut, maka media pembelajaran Lectora Inspire dipilih guru untuk menyampaikan materi pelajaran di kelas. Dengan media pembelajaran ini guru dapat membuat materi uji yang interaktif dan menyenangkan. Guru juga dapat menambah beberapa program tambahan agar dapat menampilkan fitur secara optimal sehingga informasi yang berupa tulisan, animasi serta suara yang ditampilkan sehingga membuat siswa lebih tertarik dalam mengikuti pembelajaran.

Penelitian yang dilakukan oleh Erlin (2013) menunjukkan bahwa melalui penggunaan media pembelajaran berbasis ICT dengan aplikasi Lectora Inspire ternyata banyak keuntungan yang diperoleh, antara lain: (a) media pembelajaran Lectora Inspire bila dirancang dengan baik, merupakan media pembelajaran yang efektif, dapat memudahkan dan meningkatkan kualitas pembelajaran, (b) mendukung pembelajaran individual sesuai kemampuan siswa, serta dapat digunakan sebagai penyampai balikan langsung, (c) materi dapat diulang-ulang sesuai keperluan, tanpa menimbulkan rasa jenuh, (d) hambatan dalam pemanfaatan media pembelajaran berbasis ICT dengan aplikasi Lectora Inspire adalah sumber daya manusia, (e) penggunaan media pembelajaran berbasis ICT dengan aplikasi Lectora Inspire mampu meningkatkan kualitas pembelajaran IPA, hal ini disebabkan karena melalui penggunaan media pembelajaran berbasis ICT dengan aplikasi Lectora Inspire siswa lebih tertarik, selain itu siswa yang lamban dalam daya penerimaan dapat menyesuaikan diri.

Pelaksanaan PBM dalam penelitian ini adalah dengan model pembelajaran kooperatif tipe think-pairshare. Think-pair-share memiliki prosedur secara eksplisit dapat memberi siswa waktu lebih banyak untuk berpikir, menjawab, saling membantu satu sama lain (Ibrahim, 2000). Dengan cara ini diharapkan siswa mampu bekerja sama, saling membutuhkan dan saling bergantung pada kelompok-kelompok kecil secara kooperatif. Model pembelajaran kooperatif tipe thinkpair-share ini digunakan karena memiliki kelebihan: a) memungkinkan siswa untuk merumuskan dan mengajukan pertanyaan-pertanyaan mengenai materi yang diajarkan karena secara tidak langsung memperoleh contoh pertanyaan yang diajukan oleh guru, serta memperoleh kesempatan untuk memikirkan materi yang diajarkan b) siswa akan terlatih menerapkan konsep karena bertukar pendapat dan pemikiran dengan temannya untuk mendapatkan kesepakatan dalam memecahkan masalah, c) siswa lebih aktif dalam pembelajaran karena menyelesaikan tugasnya dalam kelompok, dimana tiap kelompok hanya terdiri dari 2 orang, d) siswa memperoleh kesempatan untuk mempersentasikan hasil diskusinya dengan seluruh siswa sehingga ide yang ada menyebar, e) memungkinkan guru untuk lebih banyak memantau siswa dalam proses pembelajaran.

Berdasarkan latar belakang diatas, rumusan masalah yang akan dipecahkan dalam penelitian ini adalah Bagaimanakah keefektifan perangkat pembelajaran model TPS dengan media Lectora Inspire untuk meningkatkan hasil belajar siswa? Rumusan masalah tersebut dapat dirinci dalam pertanyaan penelitian sebagai berikut: (1) Bagaimanakah kelayakan perangkat pembelajaran model TPS yang meliputi: RPP, buku siswa, LKS, media Lectora Inspire dan tes hasil belajar yang dikembangkan?, (2) Bagaimanakah kepraktisan perangkat pembelajaran model TPS dengan menggunakan media Lectora Inspire yang 
dikembangkan?, (a) Bagaimanakah keterlaksanaan RPP yang dikembangkan?, (b) Bagaimanakah aktivitas siswa selama kegiatan belajar mengajar?, (c) Bagaimanakah respon siswa terhadap setelah mengikuti pembelajaran menggunakan perangkat pembelajaran dengan media Lectora Inspire?, (3) Bagaimanakah peningkatan hasil belajar siswa setelah dilakukan implementasi pembelajaran dengan media Lectora Inspire?, dan (4) Kendala-kendala apa sajakah yang terjadi selama proses pembelajaran menggunakan perangkat pembelajaran dengan media Lectora Inspire serta bagaimana solusinya?

Tujuan umum penilitian ini adalah "Mengembangkan perangkat pembelajaran model TPS dengan media Lectora Inspire untuk meningkatkan hasil belajar siswa". Tujuan khusus, meliputi: (1) Mendesksripsikan validitas perangkat pembelajaran model TPS dengan media Lectora Inspire yang dikembangkan berdasarkan kelayakan RPP, buku siswa, LKS, dan media Lectora Inspire, (2) Mendeskripsikan keterlaksanaan perangkat pembelajaran model TPS dengan menggunakan media Lectora Inspire, (3) Mendeskripsikan aktivitas siswa selama proses pembelajaran yang menggunakan perangkat pembelajaran model TPS dengan media Lectora Inspire, (4) Mendeskripsikan peningkatan hasil belajar siswa setelah proses pembelajaran menggunakan perangkat pembelajaran model TPS dengan media Lectora Inspire, (5) Mendeskripsikan respon siswa setelah mengikuti pembelajaran dengan menggunakan perangkat pembelajaran model TPS dengan media Lectora Inspire, (6) Mendeskripsikan kendala-kendala yang terjadi selama proses pembelajaran dengan menggunakan perangkat pembelajaran model TPS dengan media Lectora Inspire.

\section{METODE PENELITIAN}

Penelitian ini dilaksanakan di SMAN Mojoagung - Jombang pada tanggal 12 - 25 November 2013. subyek dalam penelitian ini adalah media Lectora Inspire yang digunakan dalam pembelajaran siswa kelas X-1 (laki-laki 13, perempuan 17), X-2 (laki-laki 13, perempuan 17), X-3 (laki-laki 10, perempuan 20) tahun pelajaran 2013/2014. Rancangan penelitian ini mengacu pada model pengembangan perangkat pembelajaran 4-D Thiagarajan dengan 3 kali replikasi. Bagan rancangan penelitian yang digunakan adalah sebagai berikut (Prabowo, 2011):

\begin{tabular}{|l|l|l|l|}
\hline 1 & $\mathrm{U}_{1}$ & $\mathrm{~L}$ & $\mathrm{U}_{2}$ \\
\hline 2 & $\mathrm{U}_{1}$ & $\mathrm{~L}$ & $\mathrm{U}_{2}$ \\
\hline 3 & $\mathrm{U}_{1}$ & $\mathrm{~L}$ & $\mathrm{U}_{2}$ \\
\hline
\end{tabular}

Keterangan:

$\mathrm{U}_{1}$ adalah pretest untuk mengetahui penguasaan siswa terhadap materi pelajaran sebelum pembelajaran berlangsung

$\mathrm{U}_{2}$ adalah posttest untuk mengetahui penguasaan siswa terhadap materi pelajaran setelah pembelajaran berlangsung
L adalah perlakuan melalui penerapan media pembelajaran Lectora Inspire.

Teknik pengumpulan data dalam penelitian ini menggunakan beberapa cara, antara lain: (1) Validasi perangkat untuk mengetahui kualitas perangkat pembelajaran dengan menggunakan lembar validasi perangkat oleh validator yang terdiri dari pakar, (2) Observasi/Pengamatan dipergunakan dalam penelitian ini untuk mengumpulkan data tentang keterlaksanaan pembelajaran, respon siswa, dan kendala-kendala yang ditemui selama pembelajaran berlangsung, (3) Angket digunakan untuk mengumpulkan data penelitian mengenai respon siswa. Angket ini diberikan pada akhir penelitian, pengisian angket dilakukan siswa tanpa ada tekanan dari pihak manapun, (4) Tes hasi belajar Tes terdiri dari pretest-postest yang digunakan untuk mengetahui hasil belajar siswa. Pretest diberikan sebelum pembelajaran dengan media Lectora Inspire diberikan dengan tujuan mengidentifikasi kemampuan awal siswa. Postest diberikan pada akhir penelitian setelah pembelajaran dengan media Lectora Inspire bertujuan untuk mengetahui ketuntasan belajar siswa. Tes hasil belajar berupa 10 soal pilihan ganda.

Data kualitatif yang telah digambarkan dengan kata-kata, dipisahkan menurut kategori kemudian dilakukan analisis dengan dua cara, yaitu: (1) Dijumlahkan, dibandingkan dengan jumlah yang diharapkan kemudian dideskripsikan dengan membandingkan dengan kriteria yang telah ditetapkan, seperti yang dilakukan pada data hasil belajar dan keterlaksanaan RPP, (2) Dijumlahkan dan diklasifikasikan kemudian dideskripsikan kesimpulannya, seperti yang dilakukan pada data respon siswa. Adanya peningkatan hasil belajar siswa dapat diketahui melalui analisis Normalized-Gain (NGain). Siswa mengalami peningkatan hasil belajar tinggi apabila $N$-Gain $\geq 0,7,0,3 \leq N$-Gain $\geq 0,7=$ sedang, dan $N$-Gain $<0,3$ rendah (Hake, 1998).

\section{HASIL DAN PEMBAHASAN}

Berdasarkan hasil analisis dan pembahasan, maka didapatkan temuan hasil penelitian sebagai berikut: (1) Perangkat pembelajaran yang dikembangkan baik dan layak digunakan dalam pembelajaran karena hasil penelitian menunjukkan: (a) Hasil Validasi RPP, Hasil penilaian RPP oleh pakar yang meliputi aspek tujuan pembelajaran, kegiatan pembelajaran, waktu, perangkat pembelajaran, metode sajian, dan bahasa mendapatkan nilai rata-rata 3,9 dengan reliabilitas $83 \%$, hal ini berarti RPP yang dikembangkan layak dan reliabel dijadikan panduan guru dalam mengelola pembelajaran, (b) Hasil Validasi Buku Siswa, Penilaian buku siswa yang meliputi aspek komponen kelayakan, komponen kebahasaan, dan komponen penyajian masing-masing memperoleh nilai 3,$9 ; 3,9 ;$ dan 4,0 dengan rata-rata 3,9 dengan reliabilitas $86 \%$. Artinya buku siswa yang dikembangkan layak dijadikan buku panduan bagi siswa dalam pembelajaran, (c) Hasil Validasi LKS, Hasil penilaian LKS memperoleh nilai rata-rata 4,0 dengan reliabilitas 93\%. Hal ini menunjukkan bahwa 
LKS yang dikembangkan layak digunakan oleh siswa dalam pembelajaran.

Hasil Validasi Media Lectora Inspire, (d) Penilaian yang diperoleh terhadap media Lectora Inspire memperoleh nilai rata-rata 3,9 dengan reliabilitas $88 \%$. Hal ini berarti media pembelajaran Lectora Inspire layak digunakan dalaam pembelajaran, (e) Hasil Validasi Tes Hasil Belajar (THB), Hasil penilaian terhadap tes hasil belajar diperoleh nilai 3,9 dengan reliabilitas $81 \%$. Artinya bahwa tes hasil belajar ini layak digunakan siswa dan guru dalam pembelajaran. (2) Keterlaksanaan RPP, (a) Keterlaksanaan RPP pada ujicoba II dapat terlaksana $100 \%$, dengan reliabilitas sebesar 94\%. Rata-rata skor untuk 3 replikasi kegiatan pendahuluan rata-rata skor 3,9 berarti baik, kegiatan inti rata-rata skor 3,8 yang berarti baik, dan penutup rata-rata skor 3,9 yang berarti baik. Hal ini menunjukkan RPP terlaksana dengan baik dan reliable, (b) Aktvitas siswa paling banyak dalam kegiatan belajar mengajar dengan media Lectora Inspire adalah siswa mengajukan/menjawab pertanyaan yang ada dalam Lectora Inspire dengan rata-rata 17,3\% untuk 3 replikasi, (c) Respon positif siswa terhadap materi ajar, media Lectora Inspire, buku siswa, LKS, suasana belajar, dan cara guru mengajar adalah 96\%98\% merasa tertarik dan 89\%-92\% merasa baru terhadap komponen tersebut. Untuk respon siswa terhadap bahasa dalam buku, materi atau isi buku, LKS, contoh soal, dan cara guru mengajar adalah 91\%-93\% merasa mudah memahami. Respon siswa jika pembelajaran selanjutnya atau pelajaran lain menggunakan media Lectora Inspire sebesar 93\%-97\%. Siswa merasa jelas untuk respon terhadap penjelasan guru pada saat KBM sebesar 90\%-97\%. Respon siswa terhadap kemudahan menjawab butir soal sebesar 77\%$83 \%$. (3) Adanya peningkatan hasil belajar siswa setelah diterapkan pembelajaran dengan media Lectora Inspire, hal ini dikarenakan hasil penelitian menunjukkan: Hasil belajar siswa menunjukkan peningkatan dari skor rata-rata untuk replika $1,2,3$ $(34,7 ; 43,0 ; 42,9)$ untuk pretest dan $(79,8 ; 83,5 ; 85,5)$ untuk skor rata-rata untuk replika 1, 2, 3 posttest dengan ketuntasan untuk replika 1, 2, 3 (90\%, 93\%, $100 \%$ ). Peningkatan hasil belajar siswa pada penelitian ini tidak terlepas dari media pembelajaran Lectora Inspire, karena sebelum perlakuan dengan menggunakan media Lectora Inspire nilai hasil belajar siswa hanya mencapai nilai rata-rata 34,7. Menurut Sunyoto (2006) bila seseorang terus menerus melihat dan mengamati suatu objek/gambar bergerak dengan penyajian yang menarik, maka dapat dipastikan seseorang akan termotivasi untuk memperhatikan dan mempelajarinya sehingga seseorang itu hafal dan paham dan berpengaruh terhadap prestasinya. Hasil penelitian yang menyatakan hasil positif pembelajaran menggunakan media animasi ini diperkuat peneliti lain seperti O'day (2007) yang menyatakan bahwa animasi menyediakan suatu cara untuk berkomunikasi yang melibatkan urutan komplek secara jelas dan efisien. Stith (2004) mengemukakan bahwa penggunaan animasi dan simulasi akan berdampak dalam peningkatan belajar. Sankar (2010) menyatakan pembelajaran berbasis multimedia dapat memudahkan siswa dalam memahami materi, karena dapat menghadirkan kejadian-kejadian alam secara nyata di ruang kelas.

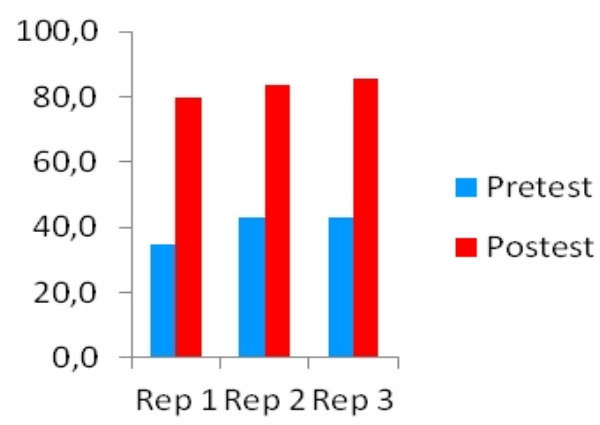

Gambar 1. Hasil Pretest-Posttest

Dengan Normalized Gain (0,68 sedang; 0,70 tinggi; 0,74 tinggi).

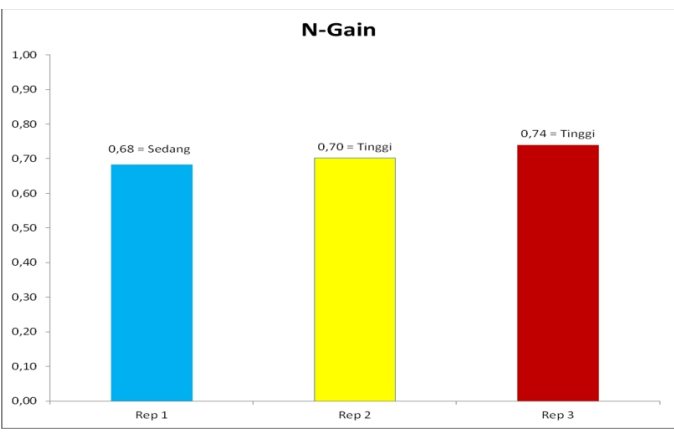

Gambar 2. N-Gain

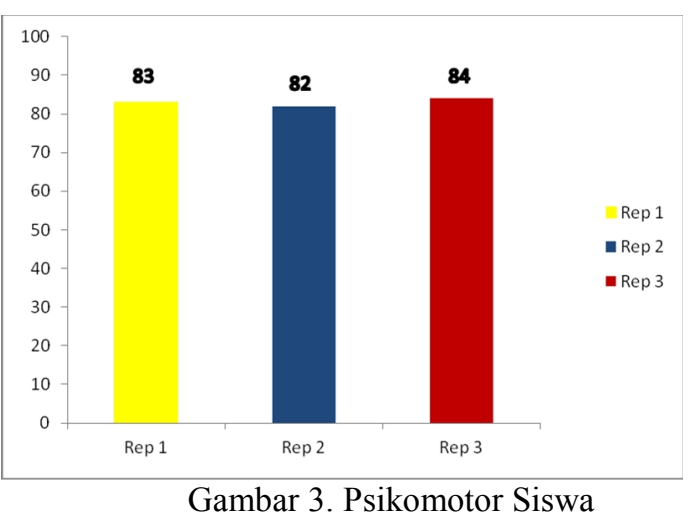

Psikomotor siswa juga mengalami peningkatan dari tiga replikasi dengan presentase rata-rata tiap replikasi 83 , 82 , 84. Hal ini menunjukkan kemampuan psikomotor siswa meningkat. Hal ini menunjukkan bahwa LKS yang dikembangkan dapt meningkatkan kemampuan psikomotor siswa. Ketuntasan Indikator sebesar 100\% yang berarti seluruh indikator mengalami ketuntasan, dan siswa mampu menguasai seluruh indikator. Sensitivitas butir soal didapatkan rata-rata 0,35-0,47, hal ini berarti butir soal yang digunakan memiliki nilai sensitivitas yang baik dan peka.(4) Kendala-kendala yang ditemui selama pembelajaran dengan media Lectora Inspire adalah: (1) siswa belum terbiasa menggunakan model pembelajaran kooperatif TPS sehingga guru harus menyediakan waktu untuk menjelaskan tahapan-tahapan TPS sebelum memulai 
pembelajaran, (2) beberapa siswa belum terbiasa menghubungkan antara motivasi berupa video dengan materi yang akan dipelajari, siswa diharapkan lebih banyak menggalih informasi dari buku siswa dan media yang lain sebelum KBM berlangsung.

\section{PENUTUP}

\section{Simpulan}

Berdasarkan temuan hasil penelitian, maka dapat disimpulkan bahwa perangkat pembelajaran model TPS dengan media Lectora Inspire yang dikembangkan efektif untuk meningkatkan hasil belajar siswa.

\section{Saran}

Berdasarkan hasil penelitian yang telah dilakukan, disarankan: (1) Pengembangan perangkat pembelajaran model TPS dengan media pembelajaran Lectora Inspire ini perlu persiapan yang matang dari segi alat maupun kemampuan guru dalam mengorganisir pembelajaran. Untuk itu guru harus bisa menentukan media apa yang paling cocok digunakan untuk tiap pokok bahasan. (2) Perangkat pembelajaran model Think-Pair-Share dengan media Lectora Inspire yang dikembangkan ini dapat dijadikan alternatif dalam menerapkan kurikulum 2013.

\section{DAFTAR PUSTAKA}

Daryanto. 2010. Media Pembelajaran. Yogyakarta: Gava Media.

Erlin, W. 2013. Penerapan Media Pembelajaran Berbasis ICT dengan Aplikasi Lectora Inspire dalam Pembelajaran IPA. Jurnal Program Pascasarjana UNS Solo.

Hake. R.R. 1998. Analyzing Change Scores (online). Tersedia:

http://www.physics.indiana.edu/sdi/AnalyzingCha nge-Gain.pdf. Diunduh Rabu, 8 Januari 2014, pukul 10.00 .

Ibrahim, Muslimin, Fida R, M.Nur, Ismono. 2000. Pembelajaran Kooperatif. Surabaya: University Press Universitas Negeri Surabaya.

O'day, Danton, H. 2007. The Value of Animations in Biology Teaching: A Study of Long Term Memory Retention. A Journal of Life Science Education (online). 6.3.217-223. Diunduh Rabu, 8 Januari 2014, pukul 10.45.

Palupi, Hesti. 2011. Pengembangan Perangkat Pembelajaran Kooperatif STAD pada Pokok Bahasan Hukum Newton. Makalah Komprehensif. Pascasarjana Universitas Negeri Surabaya.

Prabowo, 2011. Metodologi Pendidikan (Sains dan Pendidikan Sains). Surabaya: Unesa University Press.

Sankar, Chetan, dkk. 2010. A Multi-Experimental Study on The Use of Multimedia Instructional Materials to Teach Technical Subject. Journal of STEM Education. Special Edition. 24-37. Diunduh Kamis, 9 Januari 2014, pukul 10.15
Sudjana, Nana, Rivai, Ahmad. (1997). Media pembelajaran. Bandung: Sinar Baru Bandung.

Sunyoto. 2006. Efektivitas Penggunaan Modul Pembelajaran Interaktif Untuk Meningkatkan Prestasi Belajar Siswa SMK Bidang Keahlian Teknik Mesin. Jurnal ATM (online). Diunduh Kamis, 9 Januari 2014, pukul 11.20.

Stith, Bradley, J. 2004. Use od Animation in Teaching Cell Biology. A Journal of Life Science Education (online). 3.3. 181-188. Diunduh Jumat, 10 Januari 2014, pukul 09.05 . 